\title{
The Effect of One-shot Multi-access Percutaneous Nephrolithotomy on Complications
}

\section{Çoklu Access Perkütan Nefrolitotominin Komplikasyonlara Etkisi}

\author{
(D) Erkan Arslan1, (D) Hakan Türk1, (D) Ahmet Sabri Öğütlü2, (D Sıtkı Ün3 \\ 1 Uşak University Faculty of Medicine, Department of Urology, Uşak, Turkiye \\ 2 Harran University Faculty of Engineering, Department of Biostatistics, Şanlıurfa, Turkiye \\ ${ }^{3}$ Denizli State Hospital, Clinic of Urology, Denizli, Turkiye
}

\section{What's known on the subject? and What does the study add?}

We hypothesized that peri- and postoperative complications may increase in multi-access percutaneous nephrolithotomy cases due to multiple damage to the kidney.

\begin{abstract}
Objective: Kidney stones can be seen as single and pelvic stones as well as complex and multiple calculi. For this reason, single-access is not always sufficient for the treatment of kidney stones and multi-access percutaneous nephrolithotomy (PCNL) may sometimes be necessary for stone removal. In this study, we aimed to investigate the effect of multi-access PCNL using the one-shot dilation technique on kidney functions and related complications.

Materials and Methods: The effects of access number on the hemoglobin and creatinine alterations, duration of operation, need for transfusion, postoperative fever, and length of hospital stay were investigated in patients who underwent PCNL due to renal stones.

Results: Single- and multi-access PCNL using the one-shot technique was performed in 329 and 79 patients, respectively. Duration of operation, duration of scopy, and length of hospital stay as well as alterations in hemoglobin and creatinine values were found to be statistically higher in the multi-access group.

Conclusion: One-shot multi-access PCNL can be safely performed for complex kidney stones due to its high stone-free rates, despite some potential complications.
\end{abstract}

Keywords: Multiple tract, Single tract, Renal stone, Transfusion

\section{Öz}

Amaç: Böbrek taşları her zaman tek ve pelvis taşı değil kompleks ve multipl taşlar şeklinde görülebilmektedir. Bu nedenle böbrek taşlarının tedavisinde her zaman tek access yeterli olmamakta ve çoklu access taşların temizlenmesi için gerekebilmektedir. Bu çalışmamızda çoklu accessin böbrek fonksiyonları ve komplikasyonlara etkisini incelemeyi amaçladık.

Gereç ve Yöntem: Böbrek taşı nedeniyle perkütan nefrolitotomi (PCNL) yapılan hastalarda access sayısının hemoglobin ve kreatinin değişimi, operasyon süresi, transfüzyon ihtiyacı, postoperatif ateş yüksekliği ve hastanede kalış sürelerine etkisi incelendi.

Bulgular: Tek access ve çoklu access PCNL yapılan, sırasıyla 329 ve 79 hasta incelendi. Operasyon süresi, skopi süresi, hastanede yatış süresi, hemoglobin değişimi ve kreatinin değişimi çoklu access grubunda istatistiksel anlamlı daha yüksek bulundu.

Sonuç: Kompleks böbrek taşları için çoklu access PCNL olası bazı komplikasyonlarla birlikte yüksek taşsızlık oranları nedeniyle güvenle uygulanabilecek bir yöntemdir.

Anahtar Kelimeler: Çoklu giriş, Tek giriş, Böbrek taşı, Transfüzyon

Correspondence: Hakan Türk MD, Uşak University Faculty of Medicine, Department of Urology, Uşak, Turkiye

Phone: +90 5555516885 E-mail: hkntrk000@gmail.com ORCID-ID: orcid.org/0000-0002-4559-301X

Received: $16.08 .2018 \quad$ Accepted: 10.11 .2018

Cite this article as: Arslan E, Türk H, Öğütlü AS, Ün S. The Effect of One-shot Multi-access Percutaneous Nephrolithotomy on Complications. J Urol Surg 2019;6(1):16-20.

${ }^{\circ}$ Copyright 2019 by the Association of Urological Surgery / Journal of Urological Surgery published by Galenos Publishing House. 


\section{Introduction}

Percutaneous nephrolithotomy (PCNL) is a method with proven surgical efficacy and it is performed in kidney stones over $20 \mathrm{~mm}$ with high success and minimal morbidity rates $(1,2)$. However, kidney stones are not always seen in standard and normal structure kidneys but also in anomalous kidneys. Also, kidney stones are not always single and pelvic but can be complex and multiple. For this reason, single-access is not always sufficient for the treatment of kidney stones and multiaccess is sometimes required for stone removal. The effect of multi-access on renal functions, as well as complications, such as low hemoglobin $(\mathrm{Hb})$ values and postoperative infection, is a controversial issue $(3,4)$.

Patients who underwent PCNL in our clinic were reviewed retrospectively to evaluate the effects of one-shot singleand multi-access PCNL on complications during and after the procedure. We hypothesized that peri- and postoperative complications may increase in patients undergoing multi-access PCNL due to multiple damages to the kidney.

\section{Materials and Methods}

PCNL operations performed in our clinic between January 2015 and May 2018 were retrospectively reviewed. The surgical operations were performed by three different surgeons. Detailed information on age, gender, stone-skin distance, body mass index, number, size and location of stones, complete blood count, complete urine analysis, bleeding profile, preoperative blood biochemistry and creatinine clearance were taken from the patient records. For stone diameter, the longest diameter was measured on non-contrast computed tomography (CT) images (5). Perioperative complications, alterations in hematocrit and creatinine values, operation and scopy duration, transfusion status, postoperative fever and length of hospital stay were evaluated. After the placement of a guide catheter, tract was created by first dilating using a $6 \mathrm{~F} \mathrm{Amplatz} \mathrm{dilator} \mathrm{set,} \mathrm{then} \mathrm{with}$ one-shot method by using 25-30F dilator. Percutaneous access to the kidney was obtained under fluoroscopic guidance. A 26$\mathrm{Fr}$ rigid nephroscope was inserted through a $30-\mathrm{Fr}$ sheath. The stones were broken up using a pneumatic or ultrasonic litotripter and the small pieces were taken out with foreign body holders. If the stone burden could not be effectively removed via 1 tract, additional tracts were obtained at the surgeon's discretion. Due to its unavailability in our clinic, we did not use flexible nephroscope and we made another access. A nephrostomy tube was placed at the end of the procedure and all patients were monitored overnight. Perioperative complications were defined as hemorrhage during PCNL that may reduce vision, hypotension, extravasation and collecting system perforation. In patients without complications, the nephrostomy tube was removed on postoperative day 1 . Also, hematocrit measurement and serum biochemistry were performed and creatinine clearance was calculated on the first postoperative day.

The presence of residual stones and kidney functions were evaluated during the first postoperative month by spiral CT. Stone-free status or presence of asymptomatic, non-infectious, non-obstructive stones that are smaller than $4 \mathrm{~mm}$ (clinically insignificant residual fragmentations) was considered surgical success.

\section{Statistical Analysis}

IBM Statistical Package for Social Sciences (Chicago, IL) version 20 was used for statistical analysis. Differences between the groups were assessed by a chi-square test for categorical variables, by Student's t-test or Mann-Whitney $U$ test for continuous variables. A p value of less than 0.05 was considered statistically significant.

\section{Results}

One-shot single-access and multi-access PCNL were performed in 330 and 79 patients, respectively. Two accesses was performed in $50(63.3 \%)$ patients, 3 accesses in $21(26.6 \%)$ and 4 accesses in $8(10.1 \%)$. The mean age of the patients in single-access and multi-access groups was $49.02 \pm 14.2$ years and $51.06 \pm 13.3$ years, respectively, with no significant difference between the two groups $(p=0.25)$. The male-to-female ratio in single-access and multi-access group groups was 215/115 and 52/27, respectively. According to the chi square test, there was no statistically significant difference in gender distribution between the two groups ( $p=0.91)$.

There was no statistically significant difference in stone location between the groups $(p=0.9)$. The stones were mostly located in the pelvis and calyx in the multi-access group in comparison to the other group $(p=0.003)$ (Table 1$)$.

As for the duration of operations and duration of the scopies, both were significantly longer in the multi-access group ( $p=0.0001, p=0.0001)$. Similarly, the length of hospital stay was significantly longer in the multi-access group than in singleaccess group ( $p=0.034$ ) (Table 2). Reoperative creatinine level was significantly higher $(1.55 \mathrm{mg} / \mathrm{dL}$ vs $1.09 \mathrm{mg} / \mathrm{dL}, \mathrm{p}=0.04)$ and creatinine clearance was lower $(75.7 \mathrm{~mL} / \mathrm{min}$ vs $90.1 \mathrm{~mL} / \mathrm{min}$; $\mathrm{p}<0.05)$ in the multi-access group than in the single-access group. Similarly, postoperative creatinine level and change in creatinine clearance were significantly increased in the multiaccess group than in the single-access group $(0.43 \mathrm{mg} / \mathrm{dL}$ vs 0.1 $\mathrm{mg} / \mathrm{dL}, \mathrm{p}<0.05,10.8 \mathrm{~mL} / \mathrm{min}$ vs $3.4 \mathrm{~mL} / \mathrm{min} ; \mathrm{p}<0.05$ ) (Table 3 ).

Preoperative $\mathrm{Hb}$ was lower in the multi-access group in comparison to single-access group $(11.5 \mathrm{~g} / \mathrm{dL}$ vs $13.1 \mathrm{~g} / \mathrm{dL}$, $\mathrm{p}<0.05$ ) and postoperative decrease in $\mathrm{Hb}$ was more significant 
Table 1. Patient characteristics

\begin{tabular}{llll}
\hline & Single access & Multiple access & $\begin{array}{l}\mathbf{p} \\
\text { values }\end{array}$ \\
\hline Age (year) & $49.02 \pm 14.2$ & $51.06 \pm 13.3$ & 0.25 \\
\hline Gender (\%) & & & 910 \\
\hline Female & $115(34.8)$ & $27(34.1)$ & - \\
\hline Male & $215(65.2)$ & $52(65.9)$ & - \\
\hline Stone site (\%) & & & 0.9 \\
\hline Right & $166(50.3)$ & $41(51.8)$ & - \\
\hline Left & $164(49.7)$ & $38(48.2)$ & - \\
\hline Stone location (\%) & & & 3 \\
\hline Calyx & $49(14.8)$ & $16(20.2)$ & - \\
\hline Pelvis & $96(29)$ & $8(10.2)$ & - \\
\hline Calyx + pelvis & $185(56.2)$ & $55(69.6)$ & - \\
\hline Stone size (mm $\left.{ }^{2}\right)$ & $892.17 \pm 700.3$ & $1238.35 \pm 1240.4$ & 3 \\
\hline SSD (mm) & $84.33 \pm 22.9$ & $86.86 \pm 21$ & 0.27 \\
\hline BMI & $28.39 \pm 5.6$ & $27.1 \pm 4.8$ & 326 \\
\hline $\begin{array}{l}\text { Operative time } \\
\text { (minute) }\end{array}$ & $80.99 \pm 143.7$ & $113.67 \pm 55.3$ & 0.0001 \\
\hline Scopy time (second) & $146.02 \pm 143.8$ & $198.83 \pm 132.6$ & 0.0001 \\
\hline BMI: Body mass index, SSD: Stone-skin distance & & \\
\hline & & &
\end{tabular}

Table 2. Analysis of demographic data and operative data of patients

\begin{tabular}{llll}
\hline & Single tract & $\begin{array}{l}\text { Multiple } \\
\text { tract }\end{array}$ & $\begin{array}{l}\mathbf{p} \\
\text { values }\end{array}$ \\
\hline Perioperative complications & & 0.97 \\
\hline Positive & $36(10.9)$ & $7(8.8)$ & - \\
\hline Negative & $294(89.1)$ & $72(91.2)$ & - \\
\hline Malecot period (day) & $1.54 \pm 1.8$ & $1.68 \pm 1.4$ & 0.125 \\
\hline Postoperative fever & & & 0.160 \\
\hline Positive & $33(10)$ & $12(15.1)$ & - \\
\hline Negative & $297(90)$ & $67(84.9)$ & - \\
\hline Rezidal stone & & & 0.053 \\
\hline Positive & $61(18.4)$ & $7(8.8)$ & - \\
\hline Negative & $269(81.6)$ & $72(91.2)$ & - \\
\hline Postoperative hospital stay & & & 0.984 \\
\hline Positive & $29(8.7)$ & $7(8.8)$ & - \\
\hline Negative & $301(91.3)$ & $72(91.2)$ & - \\
\hline Total hospital stay (days) & $1.86 \pm 2.4$ & $2.60 \pm 2.4$ & $0.034^{*}$ \\
\hline *Statistically significant & & & \\
\hline
\end{tabular}

in the multi-access group ( $3.6 \mathrm{~g} / \mathrm{dL}$ vs $0.9 \mathrm{~g} / \mathrm{dL}, \mathrm{p}<0.05)$. In the multi-access group, $8(10 \%)$ patients needed transfusion and a total of 17 units of erythrocyte suspension were administered. In the single-access group 12 (3\%) patients needed transfusion and a total of 19 units of red blood cells were transfused $(p=0.04)$ (Table 4$)$.
Table 3. Comparison of creatinine and creatinine clearance levels in the two groups in patients before and after percutaneous nephrolithotripsy

\begin{tabular}{llll}
\hline & Single tract & Multiple tract & p values \\
\hline $\begin{array}{l}\text { Mean serum creatinine } \\
\text { preoperative }(\mathrm{mg} / \mathrm{dL})\end{array}$ & $1.55 \pm 1.3$ & $1.09 \pm 0.38$ & 0.04 \\
\hline $\begin{array}{l}\text { Mean serum creatinine } \\
\text { postoperative }(\mathrm{mg} / \mathrm{dL})\end{array}$ & $1.98 \pm 1.59$ & $1.21 \pm 0.61$ & $<0.05$ \\
\hline Change & $0.43 \pm 0.54$ & $0.1 \pm 0.32$ & $<0.05$ \\
\hline $\begin{array}{l}\text { Mean creatinine clearance } \\
\text { preoperative }(\mathrm{mL} / \mathrm{min})\end{array}$ & $75.7 \pm 40.8$ & $90.1 \pm 42.1$ & $<0.05$ \\
\hline $\begin{array}{l}\text { Mean creatinine } \\
\text { postoperative }(\mathrm{mL} / \mathrm{min})\end{array}$ & $66.9 \pm 38.2$ & $86.7 \pm 43.1$ & 0.01 \\
\begin{tabular}{l} 
Change \\
\hline
\end{tabular} & $10.8 \pm 10.2$ & $3.4 \pm 12.2$ & $<0.05$ \\
\hline
\end{tabular}

Table 4. Comparison of hemoglobin levels in the two groups in patients before and after percutaneous nephrolithotripsy

\begin{tabular}{llll}
\hline & Multi tract & Single tract & p values \\
\hline $\begin{array}{l}\text { Mean preoperative } \mathrm{Hb} \\
(\mathrm{g} / \mathrm{dL})\end{array}$ & $11.50 \pm 2.51$ & $13.10 \pm 2.11$ & $<0.05$ \\
\hline $\begin{array}{l}\text { Mean postoperative } \mathrm{Hb} \\
(\mathrm{g} / \mathrm{dL})\end{array}$ & $8.90 \pm 1.87$ & $12.20 \pm 2.03$ & $<0.05$ \\
\hline Drop in $\mathrm{Hb}(\mathrm{g} / \mathrm{dL})$ & 3.60 & 0.90 & $<0.05$ \\
\hline $\begin{array}{l}\text { Number of patients } \\
\text { transfused }(\%)\end{array}$ & $8(10)$ & $12(3)$ & 0.04 \\
\hline Hb: Hemoglobin & & & \\
\hline
\end{tabular}

\section{Discussion}

PCNL is the treatment method of choice for large and complex renal stones. Occasionally, more than one access may be required to completely clear the kidney stones so that a second intervention will be avoidable. It has been reported that multiaccess in PCNL was not associated with any adverse effects on kidney function (3). However, there are data in some reports showing that multi-access would increase blood loss $(6,7)$. In addition, Cho et al. (3) demonstrated that multi-access was as safe and effective as single-access in small stones, as a versatile method which can also be used for complex stones. The American Urological Association (AUA) guideline also suggested that PCNL with multiple tracts was a safe and effective way for treating staghorn stones, with monotherapy stone-free rate of $79 \%$, and acute complication rate of $15 \%$ (8). We studied the outcomes of PCNL incorporating the use of multiple tracts and single tract. In this study, most patients required three tracts to gain access to the calculi in the various calices. Patients with multi-access PCNL had a stone-free rate of 91.2\%. Patients who underwent single-access PCNL had a stone-free rate of $89.1 \%$. This result parallels the high stone-free rate achieved by PCNL monotherapy highlighted in the AUA panel report (9). Since the parenchyma is injured more than one point in multi-access PCNL, both the amount of and the risk of bleeding is expected to be 
greater than in single-access. It has been shown that the need for blood transfusion was more common in patients undergoing multi-access PCNL than in those having single-access PCNL $(9,10,11,12)$. On the contrary, there were also studies reporting that multi-access did not increase the need for transfusion (4). In our study, however, the need for blood transfusion was statistically significantly more in the multi-access group than in the single-access group. Blood transfusion was usually needed on the second and third postoperative days. That is to say, blood transfusion was not needed urgently but electively. None of our patients needed embolization due to bleeding. The rate of $\mathrm{Hb}$ drop in our study was slightly higher than in the literature. This may be due to the high number of patients undergoing three and four access.

There was no difference between the two groups in our study in terms of postoperative fever. Hegarty and Desai (13) also found no difference in terms of postoperative infectious complications between patients with multi- and single-access PCNL.

The mean preoperative creatinine level was higher in the multiaccess group (1.55 mg/dL) than in the single-access group (1.09 $\mathrm{mg} / \mathrm{dL}$ ). This may be attributed to a previous stone-related infection and renal injury due to obstructive stones. Postoperative creatinine values displayed a statistically significant difference between the two groups. Multiple access in PCNL was thought to be responsible for having negative effects on renal functions, with a significant increase in creatinine values in many reports $(4,13)$. There were also studies claiming the opposite, that it had no impact on kidney functions (3). In our study, however, multiple accesses were shown to cause significant variations in creatinine and the clearance of creatinine. Operative time is expected to be longer in multi-access PCNL due to the size of the stones and their dispersion. In our study too, the duration of operation was longer in the group with multiple accesses, consistent with other studies in the literature $(4,13)$. Despite longer duration of the operations, a second operation can be avoided with a high stone-free rate. The length of hospital stay showed an increase in parallel to the number of accesses. We attributed this to the higher incidence of decreased $\mathrm{Hb}$ levels and increased need for blood transfusion in the multi-access group. Again, the need for analgesia was more in the patients of this group. For these reasons, the length of hospital stay was statistically significantly longer in the multi-access group, compatible with the literature (13).

\section{Study Limitations}

As for the limitations of our study, its retrospective design, differences in demographic features of the patients in multiaccess and single-access study groups and its moderate sample size can be mentioned. We could not find any study in the literature evaluating the success and complication rates in patients with one-shot single-access and those requiring more than one access. The patients who underwent one-shot access PCNL in our clinic were reviewed retrospectively to evaluate its effects on complications during and after single- and multiaccess PCNL.

\section{Conclusion}

It was shown in patients who underwent PCNL due to kidney stones that one-shot multi-access decreased $\mathrm{Hb}$ level statistically significantly in comparison to one-shot single-access and that the need for blood transfusion was more in the multi-access group. Besides that, multi-access caused significant variation in the length of hospital stay and alterations in creatinine clearance. On the other hand, it was shown to be safe with high stone-free rates.

\section{Ethics}

Ethics Committee Approval: Retrospective study.

Informed Consent: Retrospective study.

Peer-review: Externally peer-reviewed.

\section{Authorship Contributions}

Surgical and Medical Practices: H.T., E.A., Concept: S.Ü., E.A., A.S.Ö., Design: H.T., S.Ü., Data Collection or Processing: H.T., E.A., Analysis or Interpretation: A.S.Ö., Literature Search: E.A., H.T., Writing: E.A.

Conflict of Interest: No conflict of interest was declared by the authors.

Financial Disclosure: The authors declared that this study received no financial support.

\section{References}

1. Binbay M, Akman T, Ozgor F, Yazici O, Sari E, Erbin A, Kezer C, Sarilar O, Berberoglu Y, Muslumanoglu AY. Does pelvicaliceal system anatomy affect success of percutaneous nephrolithotomy? Urology 2011;78:733-773.

2. Türk C, Knoll T, Petrik A, et al. Guidelines on Urolithiasis. European Association of Urology; 2016.

3. Cho HJ, Lee JY, Kim SW, Hwang TK. Percutaneous nephrolithotomy for complex renal calculi: is multi-tract approach ok? Can J Urol 2012;19:6360.

4. Gorbachinsky I, Wood K, Colaco M, Hemal S, Mettu J, Mirzazadeh M, Assimos DG, Gutierrez-Aćeves J. Evaluation of Renal Function after Percutaneous Nephrolithotomy-Does the Number of Percutaneous Access Tracts Matter? J Urol 2016;196:131-136.

5. Zhu Z, Wang S, Xi Q, Bai J, Yu X, Liu J. Logistic regression model for predicting stone-free rate after minimally invasive percutaneous nephrolithotomy. Urology 2011;78:32-36. 
6. Rassweiler JJ, Renner C, Eisenberger F. The management of complex renal stones. BJU Int 2000;86:919-928.

7. Akman T, Binbay M, Sari E, Yuruk E, Tepeler A, Akcay M, Muslumanoglu AY, Tefekli A. Factors affecting bleeding during percutaneous nephrolithotomy: single surgeon experience. J Endourol 2011;25:327-333.

8. Preminger GM, Assimos DG, Lingeman JE, Nakada SY, Pearle MS, Wolf JS Jr; AUA Nephrolithiasis Guideline Panel). AUA guideline on management of staghorn calculi: diagnosis and treatment recommendations. J Urol 2005;173:1991-2000.

9. Auge B, Dahm P, Bach $T$, et al. Critical analysis of multiple access PNL in managing complex renal calculi. J Endourol 2001;15:60.
10. Hegarty NJ, Desai MM. Percutaneous nephrolithotomy requiring multiple tracts: comparison of morbidity with single-tract procedures. J Endourol 2006;20:753-760.

11. Netto NR Jr, Ikonomidis J, Ikari 0 , Claro JA. Comparative study of percutaneous access for stag horn calculi. Urology 2005;65:659-662.

12. Singla M, Srivastava A, Kapoor R, Gupta N, Ansari MS, Dubey D, Kumar A. Aggressive approach to staghorn calculi-safety and efficacy of multiple tracts percutaneous nephrolithotomy. Urology 2008;71:1039-1042.

13. Hegarty NJ, Desai MM. Percutaneous nephrolithotomy requiring multiple tracts: comparison of morbidity with single-tract procedures. J Endourol 2006;20:753-760. 